Tarih Kültür ve Sanat Araştırmaları Dergisi

Revue des Recherches en Histoire Culture et Art

مجلة البحوث التاريخية و الثقافية والفنية
Vol. 6, No. 6, December 2017

Copyright (C) Karabuk University

http://kutaksam.karabuk.edu.tr

\title{
DOI: 10.7596/taksad.v6i6.1339
}

Citation: Abulhanova, Z. R., Khubbitdinova, N. A., \& Mingazova, L. I. (2017). Intertextual Links in the Context of the Problem of Folklore-Literary Relationships (with Reference to National Literature). Journal of History Culture and Art Research, 6(6), 182-186. doi:http://dx.doi.org/10.7596/taksad.v6i6.1339

\section{Intertextual Links in the Context of the Problem of Folklore-Literary Relationships (with Reference to National Literature)}

\author{
Zilya Ravilevna Abulhanova ${ }^{1}$, Narkas Ahmetovna Khubbitdinova², \\ Liailia Ihsanovna Mingazova3
}

\begin{abstract}
An attempts to apply the theory of intertextual analysis to the study of the ancient work of national literature, the Bashkir literature in particular, was made in the article. The folklore motifs used in the work mostly cause intertextual communication, an allusion to the poetic traditions of the Bashkir folklore, which are endowed with original artistic and aesthetic functions. In the frame of the article were considered the usage of the intertextual method in the study of the Turkic and Bashkir literatures, what gives a possibility to reveal the degree of correlation of works with the Eastern, Turkic-Bashkir literary and folklore traditions, to expand understanding of the semantics and poetics of literature, to define new ways of interpretation, to consider the literary heritage of the Bashkir people as an art system included in a single world context. The urgency of the work is beyond question, given that for the first time the work involves an attempt to combine traditional research methods with the theory of the intertextual analysis of a literary work.
\end{abstract}

Keywords: Folklore, Literature, The problem of folklore-literary interrelations, The theory of intertextual relations, Allusions, citations.

\footnotetext{
${ }^{1}$ Graduate student, Kazan Federal University, Tatarstan, 420008, Kazan, Kremlin Street, 18.

2 Leading Researcher of the Department of Literature -Institute of history, language and literature, Ufa Scientific Center RAS.

3 Graduate student, Kazan Federal University, Tatarstan, 420008, Kazan, Kremlin Street, 18. E-mail: Leila69@inbox.ru
} 


\section{Introduction}

Structural analysis in the field of folklore and literary criticism is of particular interest, namely in the context of the problem of the interrelationships of objects of study-folklore and literature. In this case, the studies of M. Bakhtin devoted to structural and semiotic issues in the field of literature, as well as the concept of intertextuality of Yulia Kristeva, one of the prominent representatives of the founders of Bakhtin studies in Europe, formulated on the basis of Bakhtin teachings are acceptable for us. It was thanks to her works "Bakhtin, Word, Dialogue and Novel" (1967) and "Destruction of Poetics" (1970), created under the impression of the scientist's works that the Western humanitarian community learned about the Russian thinker.

\section{Methods}

In modern science there is a method of structural, system-functional, semantic study of verbal art. Originating in the 1920s on the basis of a linguistic school (F. de Saussure, IA Baudouin de Courtenay, R. Jacobson, S. Bally, etc.), historical anthropology (K. Levi-Strauss), formal school of philology (V.Ya. Propp, BV Shklovsky, Yu.N. Tynyanov, BM Eichenbaum, etc.), structuralism received a philosophical justification and the most widespread in the 1960s in France (MP Foucault, R. Bart), in Italy (U. Eco), in the USA (M. Eliade). In Russia, the largest representatives of structuralism in the field of culture in general were M.M. Bakhtin, Yu.M. Lotman, E.M. Meletinsky, V.Ya. Propp, Yu.N. Tynyanov, V.N. Axes, etc. (Medkova, 2017). This type of research were used as well by Kazan researchers as V.R. Amineva, G.G. Galimullin (2014) A.F. Galimullina (2016), L.I. Mingazova (2017) S.M. Mikhailova, H.Yu. Minnegulov, R.F. Mukhametshina, E.F. Nagumanova, Yu.G. Nigmatullina, R.R. Zamaletdinov, A.M. Sayapova, F.S. Safiullina (2013).

Structural linguistics is the methodological basis for structuralists. The success of the movement of structuralists, embracing other areas of culture (cultural anthropology, folklore, literary criticism), contributed to the development of semiotics, i.e. analysis of various phenomena in terms of sign systems.

\section{Results and Discussion}

When considering some of the works of the national, in this case Bashkir and Russian literature, in which expressive intertextual links are particularly pronounced, this article for the first time attempted to combine traditional research methods with the theory of the intertextual analysis of a literary work. In this direction, the works, separate articles and speeches by M. Bakhtin, K. Levi-Strauss, Yulia Kristeva, Yu. M. Lotman, R. Lachmann, I.P. Ilyin, R. Barth, and others.

The problem of intertextual communication, in other words intertextuality, in folklore and literary criticism is the transformation of texts throughout the history of literature. In the process of such changes and modifications, this or that artistic work, in particular, folklore subjects, motifs, are borrowed, reinterpreted, interpreted in the literature. In this case, intertextual analysis, in the context of literary analysis, helps to identify, so-called "other people's words", "textual convergence", and to identify and indicate their functional significance in the artistic and aesthetic sense.

Despite the fact that the terms "intertext" and "intertextuality" were introduced relatively recently, but some hint of them in the form of intertextual links, "dialogue" texts are found in the research of Russian scientists in the 1920s. Problems associated with the fact of "borrowing" - "reminiscences", intertextual relations - "convergence" developed in the works of B.V. Tomashevsky, who studied the work of A.S. Pushkin in this aspect. The impact of some writers on others (for example, writers of the older generation on the younger), as he believed, is not limited to "finding borrowings and reminiscences in texts." Accordingly, the scientist should distinguish between different kinds of textual convergence. For example, 
if there is "a conscious citation - a hint, a reference to a senior writer", then "in what coverage is this quote given"; it is necessary to find out whether there is an "unconscious reproduction of a literary template", "filling a vacant place in the background of a literary work," and finally, is there "an accidental coincidence of words that came side by side in a combination of the young writer completely independent and influenced by other, independent artistic impulses than in the works of the authors of the previous generation", etc. Without taking all these features into account, the detected "parallels" will have the character of a little meaningless "raw material," and "seeking out these parallels" outside of understanding their nature, essence, function will be something like "literary collecting" (Tomashevsky, 1960, p.81-82). In our case, we can talk about all the reminiscences expressed about national literature, where both conscious and unconscious or unconscious, "accidental" borrowings, citations, allusions to folklore traditions were found. Expressed by B. Tomashevsky unconscious in the work of a young writer in his understanding, consisting in "reproducing the literary template" for "filling an empty space" in a literary work, it is possible that it is characteristic not only of inter-literary, but also of folk-literary interrelations.

Types, forms of intertextuality are familiar to us from time immemorial. Below them in the science called borrowing, recycling themes and subjects, overt and covert citation, translation, plagiarism, allusion, imitation, parody, the film adaptation, the use of epigraphs, etc. Relatively folklore borrowing in the literature, the use of folk motifs in the literature, O. Trykova offered the following types: narrative borrowing (paraphrase); structural borrowing; functional borrowing; motivational borrowing; figurative borrowings; citation of folklore works; reworking of folklore texts, it modernized and mimicking (ie styling - NH...); use of tropes, art techniques and folklore (Trykova, 1999, p.3) could be added to it such types and species are hidden and explicit citation in the folk stories, motifs, images for the sake of completeness with respect to our study of the subject of folklore and literary intertexts; translation, use of epigraphs (in particular, in the context of Bashkir-Russian folklore and literary relationships); allusion, reminiscence in the literature on folklore, etc.

For clarity, let us turn to some examples from Bashkir literature. Being a part of the world culture, she could not remain aloof from other literatures; she lived, developed, interacted with them, thereby enriching herself and with her enriching others. Folklore, being the primary source to which writers of many generations refer and refer, is in the literature an object of artistic rethinking, use. As a result, there is an intertextual connection with the plot, the motive of the literary work.

While conducting research in the traditional channel, in the literary work it is possible to distinguish folkloric motifs, images, rituals, study their ideological and artistic functions, ideological and aesthetic significance, etc. So, in the famous "Kissa-i Yusuf" (1212) of the Turkic poet Kul Gali, who created in the ancient city of Bulgar, located in the Ural-Volga region, the motif associated with a dream prophetic dream, reminiscent of folklore dream motif, on which in the work is entrusted with an important ideological and aesthetic function and which is the cause of the development of the plot in one direction or another, plays an important role in the fate of the hero, etc. (Gali Kul). Created in ancient times, the story of Yusuf Beautiful and Zuleikha, was in demand and is relevant at all times. He was included in the Old Testament, the Bible, in the holy scripture "The Koran" (12th Surah); He inspired the words of the East, the West: Firdausi, Durbek, Ansari, Kul Gali, Yamida, Shota Rustaveli, Hamza, Thomas Mann, Jan Reinist, Nazim Hikmet, who created their own interpretations and new works on the famous plot. From the point of view of intertextual discourse, the text of the monument, passed from century to century, passed from mouth to mouth, from hand to hand, experienced dialogue with its previous text, where the meaning was not just repeated, but was born again, it was replenished with qualitatively new concepts and meaning, in artistic sense - new details and motives. 
In this respect, the writer's ethnicity also mattered. He, creatively mastering the famous plot, attracts his "sculpting" material, artistically enriching the work, which, in turn, contributes to the growth of readership demand or the expression of socio-political views of their people or the ruling circle. In our case, this "sculpting" material for Kul Gali in the creation of his work about Yusuf the Beautiful was folkloric traditions, the echoes of which we can see in Bashkir folk art (the stories of many fairy tales, epic monuments are built on the motive "Prophetic sleep", "In a dream fell in love - married in reality", "Love triangle", often there are images of "Just ruler", "Injured relative", stepdaughter, etc.).

In the process of working on his work, Kul Gali, in addition to the contemporary reality, could not help referring to both the literature of his time and the literature of the past centuries or the folklore heritage and to be with him in constant "dialogue". Moreover, according to the observations of folklorists, the peoples of the medieval Ural-Volga region, including the Bashkirs, knew epic works in which traditional motifs and images were stably traced (dastans "Yusuf-Zuleikha", "Buzeget", "Takhir-Zukhra"), not to mention the numerous tales on these topics (Suleimanov, 2002, v.6, p.384-385). This contributed to the emergence of intertextual links between folklore and literature. In the kul of Kul Gali, the dream motif is the most popular, often encountered artistic element. In the ideological and artistic plan, an important function is assigned to it in the work, and it has a plot-forming nature, and also serves as a religious idea about the predetermined fate of a person. Yusuf sees a prophetic dream, predicting his rise above other mortals and finding the dignity of the saint. The insidiousness and envy of his brothers to him, the overcoming of various obstacles and hardships, the inner struggle with temptation, the painful desire to preserve his devotion to God are all tests as part of the consequences of God's prophecy. In artistic terms, the first seen prophetic dream, thus, entails a chain of other motives, serving artistic and aesthetic enrichment and improvement of the main plot.

Consequently, it was discovered in Russia in the first quarter of the 20th century. And later improved by Western European science, the theory of intertextuality applied to the national literature helps to improve the methods of studying and analyzing artistic works (as well as folklore), expanding and enriching the scientific conceptual apparatus.

\section{Conclusion}

Studying the problem from the point of view of the intertextual approach in many ways allows us to rethink the literary work, the methods of its comparative philological analysis that would help to reveal the features of the literary traditions of authors of different eras, to reveal their ideological, aesthetic, artistic positions and views. The use of the intertextual method in the study of the Turkic and Bashkir literatures makes it possible to reveal the degree of correlation of works with the Eastern, Turkic-Bashkir literary and folklore traditions, to expand understanding of the semantics and poetics of literature, to define new ways of interpretation, to consider the literary heritage of the Bashkir people as an art system included in a single world context. This problem in particular takes on relevance in the Bashkir literature before the revolutionary period, when in the work of writers folk traditions were of great importance, the authors, as bearers of ethnic mythopoetic, archetypal traditions, unconsciously used and used them in their works.

The closer the relationship between folklore and literature, where folklore thinking, folkloric imagery of the world prevailed in the author's worldview, the more intertextual connection of folklore and literature.

\section{Acknowledgements}

The work is performed according to the Russian Government Program of Competitive Growth of Kazan Federal University. 


\section{References}

Galimullin, F. G.; Galimullina, A. F. \& Mingazova, L. I. (2014). The development of the literatures of the people of the Volga region in multi-ethnic Russia. Journal of Language and Literature, 5(3), 248-252. DOI: 10.7813/jll.2014/5-3/42.

Galimullin, F. G.; Galimullina, A. F. \& Mingazova, L. I. (2016). Common roots, common spirituality: literary relationships of the tatar and Azerbaijani literature in the context of the dialogue of cultures. The Social Sciences.

Gimadieva, G. I.; Mingazova, L. I.; Sayilov, G. A. \& Sayfulina, F. S. (2017). General Roots, General Spirituality: Literary Interrelations of Literatures in the Aspect of Cultural Dialogue. Journal of History Culture and Art Research, 6(4), 497-504.

Karabulatova, I. S.; Sayfulina, F. S. \& Akhmetova, B. Z. (2013). Ethno-Lingual Aspect of Modern Functioning of Russian Dialects in North Kazakhstan (On an Example of Kostanai Region). World Applied Sciences Journal (Education, Law, Economics, Language and Communication), 27, 137-140.

Kul, G. (1985). The Legend of Yusuf. Transl. with Turkic. on rus. yaz. S. Ivanov. Kazan: Tatkhnigoizdat.

Medkova, E. S. (2017). Possibilities of pedagogical interpretation of the methodology of semiotics and structuralism in the teaching of the World Art Culture. URL: http://www.art-education.ru

Piege-Gros, N. (2007). Introduction to the theory of ittertextuality. Per. with French. G.K. Kosikova, V.Yu. Lukosik and others; Society. Ed. and entry. sl. G.Kosikova. URL: http://abuss.narod.ru/Biblio/piegegro.htm

Suleimanov, A. M. (2002). Our Kiss and Dastans. In N. Zaripov, A. Suleymanov, G. Khusainov (eds.), Bashkir folk art: Epos: Kiss and Dastans, Vol.6, (pp. 380-443). Ufa: Kitap.

Tomashevsky, B. V. (1960). Pushkin and France. London.

Trykova, O. Yu. (1999). Domestic prose of the last third of the twentieth century: genre interaction with folklore. Dissertation in Philology Science. Moscow. 